\title{
VIGOR AND TOLERANCE OF COWPEA (Vigna unguiculata) GENOTYPES UNDER SALT STRESS
}

\author{
VIGOR E TOLERÂNCIA DE GENÓTIPOS DE FEIJÃO-CAUPI (Vigna unguiculata) \\ SOB ESTRESSE SALINO
}

\section{Francisco Vanies da Silva SÁ $^{1}$; Ronaldo do NASCIMENTO ${ }^{2}$; Mariana de Oliveira PEREIRA ${ }^{1}$; Vitória Ediclécia BORGES ${ }^{3}$; Rafaela Felix Basílio GUIMARÃES ${ }^{3}$; Jailton Garcia RAMOS ${ }^{3}$; Jacqueline da Silva MENDES ${ }^{1}$; Jaílson Lopes DA PENHA ${ }^{1}$}

1. Doutorando(a) em Engenharia Agrícola, Universidade Federal de Campina Grande - UFCG, Campina Grande, PB, Brasil, vanies_agronomia@hotmail.com; 2. Professor Doutor da Universidade Federal de Campina Grande - UFCG, Campina Grande, PB, Brasil; 3. Mestrando(a) em Engenharia Agrícola, Universidade Federal de Campina Grande - UFCG, Campina Grande, PB, Brasil.

\begin{abstract}
Saline stress is a frequent phenomenon in the arid and semi-arid regions of the globe, affecting the agricultural production of these regions, and it is necessary to use strategies that minimize the impacts of saline stress under agriculture. This requires the incorporation of species, variety and genotypes tolerant to increase agricultural production in those regions. This study aimed to evaluate germination and initial growth of cowpea genotypes under salt stress. The experimental design was completely randomized in 19 × 3 factorial scheme, composed of nineteen cowpea cultivars and three osmotic potentials, with four replicates of 50 seeds each. The germination test lasted for eight days, when the seeds were evaluated for germination percentage, germination speed index, length of shoot and root, accumulation of dry mass of shoot and root. The increase in salinity affected germination and initial growth of the cowpea genotypes. The genotypes 6 - MNCO2-689F-2-8, 10 - MNCO2-675F-4-10, 12 - MNCO3-737F-5-9, 16 - MNCO2-677F-2, 18 - BRS-Pajeú and 19 - Paulistinha exhibited higher tolerance to salt stress in the stage of germination and initial growth. The genotypes 11 - MNCO2-675F-9-5, 13 - BRS-Tumucumaque, 15 - MNCO3-736F-7 and 17 - BR17-Gurgueia were more susceptible to the effects of salt stress in the stage of germination and initial growth.
\end{abstract}

KEYWORDS: Seed Physiology. Germination. Water salinity.

\section{INTRODUCTION}

Cowpea (Vigna unguiculata (L.) Walp.) has great socioeconomic importance in the northeast region of Brazil, besides being one of the basic components of the diet of the northeastern population (LIMA et al., 2011). With the expansion of cowpea cultivation, new markets and commercialization perspectives open for this crop, which requires the use of new production technologies, such as irrigation, one of the agricultural technologies that have contributed the most to the increase in food production (MURTAZA et al., 2006; LIMA et al., 2011). However, its inadequate use accelerates soil salinization, especially under semi-arid conditions (ALMEIDA et al., 2012; COELHO et al., 2014).

Although sensitive to salinity, cowpea is widely spread in semi-arid regions of Northeast Brazil, where salinity problems are frequent. Hence, one alternative to improve cowpea yield would be the study of different genetic materials subjected to conditions of high saline concentration in the soil solution, to select the most adapted ones (SANTOS et al., 2009).

The osmotic effect and toxicity of ions are the main agents of salt stress on plants, but the osmotic effect is the most damaging to germination and vigor of the plantlets, because it reduces germination speed and its uniformity, initial size and the adequate establishment of the stand (SANTOS et al., 2009; SCHEEREN et al., 2010; ALMEIDA et al., 2012). The reduction in seed vigor caused by salt stress retards, therefore, the establishment of the plantlets at the field due to the decrease in the mobilization of reserves and induction of disorders in cell membranes, caused by the increase in the osmotic pressure in the soil solution, reducing the availability of water to the seeds (BARRETO et al., 2010; ALMEIDA et al., 2012; COELHO et al., 2014).

Given the above, this study aimed to evaluate germination, initial growth and tolerance of cowpea genotypes under salt stress.

\section{MATERIAL AND METHODS}

The experiment was conducted in the Laboratory of Physiology of the Federal University of Campina Grande (UFCG), Campina Grande-PB, Brazil, from July to August 2016, using seeds of cowpea genotypes.

Twenty-six genotypes of cowpea were studied and part of them came from the Program of 
Genetic Improvement of the Embrapa Mid-North (G1 - MNCO3-736F-2; G2 - MNCO3-737F-5-11; G3 - MNCO3-736F-6; G4 - MNCO2-675F-3; G5 MNCO3-737F-11; G6 - MNCO2-689F-2-8; G7 MNCO3-737F-5-1; G8 - MNCO3-737F-5-10; G9 MNCO2-677F-5; G10 - MNCO2-675F-4-10; G11 MNCO2-675F-9-5; G12 - MNCO3-737F-5-9; G13 BRS-TUMUCUMAQUE; G14 - MNCO2-675F-93; G15 - MNCO3-736F-7; G16 - MNCO2-677F-2; G17 - BR17-GURGUEIA; G18 - BRS-PAJEÚ; G19 - PAULISTINHA) at three levels of osmotic potential: $0.0 ;-0.3$ and $-0.6 \mathrm{MPa}$, corresponding to water electrical conductivity (EC) values of 0.00 , 8.33 and $16.67 \mathrm{dS} \mathrm{m}^{-1}$, one EC value below and two EC values above the threshold salinity level for the crop (4.9 dS m${ }^{-1}$ ) (AYERS; WESTCOT, 1999), forming a $19 \times 3$ factorial scheme, with the resulting treatments arranged in a completely randomized experimental design, with four replicates and 50 seeds per plot.

The solutions used in irrigation were prepared through the addition of salts to distilled water, using sodium chloride $(\mathrm{NaCl})$, which accounts for $70 \%$ of the salt ions in water sources used for irrigation in small properties of Northeast Brazil (MEDEIROS et al., 2003).

The seeds were put in rolls of Germitest ${ }^{\circledR}$ paper, moistened until 2.5 times their dry weight, according to the treatment, and placed to germinate in a Biochemical Oxygen Demand (B.O.D.) chamber, at $25{ }^{\circ} \mathrm{C}$ and with photoperiod of 8 hours of light and 16 hours of darkness. The germination test lasted for eight days (BRASIL, 2009).

During the experiment, the germination of cowpea seeds was monitored through daily counts of the number of germinated seeds, i.e., with production of the first radicle, without discarding them, thus obtaining a cumulative value. Hence, the number of emerged plantlets referring to each count was obtained by subtracting the reading of the previous day from the value of the current day. Then, the number of germinated seeds referring to each count was used to calculate the germination speed index (GSI), based on the equation described by Maguire (1962):

$$
\mathrm{GSI}=\frac{\mathrm{G}_{1}+\mathrm{G}_{2}+\ldots+\mathrm{G}_{\mathrm{n}}}{\left(\mathrm{N}_{1}\right)+\left(\mathrm{N}_{2}\right)+\ldots+\left(\mathrm{N}_{\mathrm{n}}\right)}
$$

Where: $\mathrm{GSI}=$ germination speed index; $\mathrm{G}=$ Number of germinated seeds in each count; $\mathrm{N}=$ number of days from sowing to each count.

After the germination test, at eight days after sowing, the percentage of normal plantlets (PNP) (\%) was determined based on the relationship between the number of germinated seeds and the number of seed sown. Also at the end of the germination test, the primary root and the shoots of normal plantlets of each replicate were measured using a ruler graduated in millimeter and the results were expressed in $\mathrm{cm}$ plantlet-1. Shoot dry matter (SDM) and radicle dry matter (RDM) were determined by cutting the plantlets and storing the different portions in Kraft paper bags, which were dried in a forced-air oven at $65^{\circ} \mathrm{C}$ until constant weight and weighed on an analytical scale $(0.0001$ $\mathrm{g}$ ), with results expressed in $\mathrm{g}$ plantlet-1 (NAKAGAWA, 1999).

The obtained data were subjected to analysis of variance by $F$ test. In case of significance, the Scott-Knott means grouping test was applied for the factor genotype and the Tukey test was applied for the factor salinity, both at 0.05 significance level, using the statistical software SISVAR ${ }^{\circledR}$ (FERREIRA, 2011).

\section{RESULTS AND DISCUSSION}

There was significant interaction $(\mathrm{p}<0.05)$ between the salinity levels and studied genotypes for the variables: germination percentage, germination speed index, shoot length, radicle length, shoot dry matter and radicle dry matter (Tables 1, 2 and 3).

The germination percentage of the cowpea genotypes 4 - MNCO2-675F-3, 7 - MNCO3-737F5-1, 9 - MNCO2-677F-5, 10 - MNCO2-675F-4-10, 11 - MNCO2-675F-9-5, 13 - BRS-Tumucumaque, 14 - MNCO2-675F-9-3 and 15 - MNCO3-736F-7 was reduced from 36 to $18 \%$, due to the decrease in the osmotic potential from 0.0 $\mathrm{MPa}$ to $-0.6 \mathrm{MPa}$ (Table 1). Additionally, at the osmotic potential of $0.3 \mathrm{MPa}$, only the genotypes 11 - MNCO2-675F-95, 13 - BRS-Tumucumaque and 15 - MNCO3-736F7 showed significantly reduced $(\mathrm{p}<0.05)$ germination percentage, which indicates lower degree of tolerance of these genotypes in the germination stage (Table 1).

The germination speed index of the genotypes 4 - MNCO2-675F-3, 9 - MNCO2-677F5, 11 - MNCO2-675F-9-5, 13 - BRS-Tumucumaque and 15 - MNCO3-736F-7 was also reduced by the increase in salinity, corroborating the results of germination percentage, confirming a higher sensitivity of these genotypes to salt stress (Table $1)$. The germination percentage and germination speed index of the genotypes 3 - MNCO3-736F-6, 5 - MNCO3-737F-11, 8 - MNCO3-737F-5-10, 12 MNCO3-737F-5-9, 16 - MNCO2-677F-2, 17 BR17-Gurgueia, 18 - BRS-Pajeú and 19 Paulistinha were not influenced by the reduction in the osmotic potential from $0.0 \mathrm{MPa}$ to $-0.6 \mathrm{MPa}$ 
(Table 1), which denotes higher degree of tolerance of these genotypes in the germination stage.

Table 1. Percentage of germination (PG) and germination speed index (GSI) of cowpea genotypes under saline stress.

\begin{tabular}{|c|c|c|c|c|c|c|}
\hline \multirow{3}{*}{ Genótipos } & \multicolumn{3}{|c|}{$\mathrm{PG}(\%)$} & \multicolumn{3}{|c|}{ GSI } \\
\hline & \multicolumn{6}{|c|}{ Osmotic potential (MPa) } \\
\hline & 0.0 & -0.3 & -0.6 & 0.0 & -0.3 & -0.6 \\
\hline 1 - MNCO3-736F-2 & $80 \mathrm{Ab}$ & $66 \mathrm{Ac}$ & 67Ac & $9.65 \mathrm{Ab}$ & $6.51 \mathrm{Bc}$ & $7.08 \mathrm{Bc}$ \\
\hline 2 - MNCO3-737F-5-11 & $80 \mathrm{Ab}$ & $72 \mathrm{Ab}$ & 68Ac & $8.60 \mathrm{Ac}$ & $8.23 \mathrm{Ab}$ & $6.68 \mathrm{Bc}$ \\
\hline 3 - MNCO3-736F-6 & 94Aa & 96Aa & 95Aa & $11.58 \mathrm{Aa}$ & $11.12 \mathrm{Aa}$ & $10.44 \mathrm{Aa}$ \\
\hline 4 - MNCO2-675F-3 & 93Aa & $79 \mathrm{ABb}$ & $70 \mathrm{Bc}$ & $8.30 \mathrm{Ac}$ & $5.77 \mathrm{Bc}$ & $5.89 \mathrm{Bd}$ \\
\hline 5 - MNCO3-737F-11 & 98Aa & 94Aa & 95Aa & $12.15 \mathrm{Aa}$ & $11.54 \mathrm{Aa}$ & $10.61 \mathrm{Aa}$ \\
\hline 6 - MNCO2-689F-2-8 & 94Aa & $80 \mathrm{Ab}$ & $83 \mathrm{Ab}$ & 7.11Ad & $5.64 \mathrm{Abc}$ & $5.12 \mathrm{Be}$ \\
\hline 7 - MNCO3-737F-5-1 & $93 \mathrm{ABa}$ & 96Aa & $79 \mathrm{Bb}$ & $10.82 \mathrm{Ab}$ & $9.58 \mathrm{Ab}$ & $10.90 \mathrm{Aa}$ \\
\hline 8 - MNCO3-737F-5-10 & $100 \mathrm{Aa}$ & $100 \mathrm{Aa}$ & 98Aa & $12.32 \mathrm{Aa}$ & $12.50 \mathrm{Aa}$ & $11.66 \mathrm{Aa}$ \\
\hline 9 - MNCO2-677F-5 & $74 \mathrm{Ab}$ & $72 \mathrm{Ab}$ & $55 \mathrm{Bd}$ & $6.88 \mathrm{Ad}$ & $4.19 \mathrm{Bd}$ & $3.36 \mathrm{Bf}$ \\
\hline 10 - MNCO2-675F-4-10 & $84 \mathrm{Ab}$ & $71 \mathrm{AB}$ & $65 \mathrm{Bc}$ & $5.08 \mathrm{Ae}$ & $4.16 \mathrm{Ad}$ & $4.03 \mathrm{Ae}$ \\
\hline 11 - MNCO2-675F-9-5 & $86 \mathrm{Ab}$ & $60 \mathrm{Bc}$ & $40 \mathrm{Cd}$ & $4.60 \mathrm{Ae}$ & 5.19Ac & $2.75 \mathrm{Bf}$ \\
\hline 12 - MNCO3-737F-5-9 & 93Aa & 88Aa & $87 \mathrm{Ab}$ & $11.43 \mathrm{Aa}$ & $11.04 \mathrm{Aa}$ & $10.15 \mathrm{Aa}$ \\
\hline 13 - BRS-Tumucumaque & $79 \mathrm{Ab}$ & $52 \mathrm{Bc}$ & $61 \mathrm{Bc}$ & $8.52 \mathrm{Ac}$ & $4.93 \mathrm{Bd}$ & $4.71 \mathrm{Be}$ \\
\hline 14 - MNCO2-675F-9-3 & 88Aa & $75 \mathrm{ABb}$ & $62 \mathrm{Bc}$ & $3.94 \mathrm{Ae}$ & $4.53 \mathrm{Ad}$ & 3.10Af \\
\hline 15 - MNCO3-736F-7 & $78 \mathrm{Ab}$ & $59 \mathrm{Bc}$ & $56 \mathrm{Bd}$ & $8.75 \mathrm{Ac}$ & $5.53 \mathrm{Bc}$ & $4.50 \mathrm{Be}$ \\
\hline 16 - MNCO2-677F-2 & 96Aa & $92 \mathrm{Aa}$ & $91 \mathrm{Aa}$ & $7.85 \mathrm{Ac}$ & $8.43 \mathrm{Ab}$ & 7.37Ac \\
\hline 17 - BR17-Gurgueia & 97Aa & 95Aa & 94Aa & $12.08 \mathrm{Aa}$ & $11.55 \mathrm{Aa}$ & $11.20 \mathrm{Aa}$ \\
\hline 18 - BRS-Pajeú & $92 \mathrm{Aa}$ & 94Aa & $83 \mathrm{Ab}$ & 7.27ABd & $8.17 \mathrm{Ab}$ & $5.85 \mathrm{Bd}$ \\
\hline 19 - Paulistinha & $100 \mathrm{Aa}$ & 98Aa & $89 \mathrm{Ab}$ & $10.61 \mathrm{Ab}$ & $9.22 \mathrm{Ab}$ & $8.95 \mathrm{Ab}$ \\
\hline $\mathrm{CV}(\%)$ & & 11.31 & & & 11.86 & \\
\hline
\end{tabular}

Equal lowercase letters in the column do not differ from the Scott and Knott test $(p<0.05)$, and the same upper case letters in the row do not differ from the Tukey test $(\mathrm{p}<0.05)$.

Similar results have been reported by Santos et al. (2009), Almeida et al. (2012) and Scheeren et al. (2010), who evaluated salt stress on the germination of bean and soybean seeds, respectively, and observed that the osmotic effect compromises the germination and vigor of the plantlets, because it reduces germination speed and uniformity, initial size and the adequate establishment of the stand, because of the damage on physiological and biochemical functions due to the lower hydration of the tissues.

The reduction in the osmotic potential of the substrate from $0.0 \mathrm{MPa}$ to $-0.6 \mathrm{MPa}$ did not significantly influence $(\mathrm{p}<0.05)$ the shoot length of the genotypes 6 - MNCO2-689F-2-8, 9 - MNCO2677F-5, 12 - MNCO3-737F-5-9, 13 - BRSTumucumaque, 15 - MNCO3-736F-7 and 18 - BRSPajeú (Table 2). The reduction of growth is one of the most evident effects of the salt stress on plants, because, during the absorption of water, they concomitantly absorb $\mathrm{Na}^{+}$and $\mathrm{Cl}^{-}$ions, which in excess in the protoplasm cause ionic disorder and act on enzymes and membranes (TAIZ; ZEIGER, 2013). However, the increase in salinity negatively affected the shoot growth of the genotypes 1 MNCO3-736F-2, 3 - MNCO3-736F-6, 4 - MNCO2675F-3, 5 - MNCO3-737F-11, 8 - MNCO3-737F-510, 11 - MNCO2-675F-9-5 and 17 - BR17Gurgueia, with reductions on the order of 69.88 , $65.22,80.38,68.51,63.29,71.14$ and $82.82 \%$ in the comparison between the potentials of 0.0 and -0.6 $\mathrm{MPa}$, respectively (Table 2).

When subjected to the osmotic potential of $0.6 \mathrm{MPa}$, the radicle growth of all studied cowpea genotypes was reduced, compared with the genotypes subjected to the control treatment $(0.0$ 
$\mathrm{MPa}$ ) (Table 2). The reduction in root system is an important mechanism of tolerance under saline conditions, because it limits the entry of water and, consequently, the entry of salts, thus avoiding toxicity by specific ions (MUNS; TESTE, 2008; Oliveira et al., 2016; Sá et al., 2016). However, when subjected to intermediate conditions of salinity (-0.3 MPa), only the genotypes 6 - MNCO2689F-2-8, 13 - BRS-Tumucumaque, 15 - MNCO3-
736F-7, 16 - MNCO2-677F-2, 18 - BRS-Pajeú and 19 - Paulistinha exhibited no influence of the increase in salinity on radicle growth (Table 2). This can be related to the higher degree of tolerance of these genotypes, because the genotypes 6 MNCO2-689F-2-8 and 18 - BRS-Pajeú also showed no influence of the increase in salinity on germination and shoot growth (Tables 1 and 2).

Table 2. Length of aerial part (LAP) and radicle (LR) of cowpea genotypes under saline stress.

\begin{tabular}{|c|c|c|c|c|c|c|}
\hline \multirow{3}{*}{ Genótipos } & \multicolumn{3}{|c|}{ LAP $(\mathrm{cm})$} & \multicolumn{3}{|c|}{$\mathrm{LR}(\mathrm{cm})$} \\
\hline & \multicolumn{6}{|c|}{ Osmotic potential (MPa) } \\
\hline & 0.0 & -0.3 & -0.6 & 0.0 & -0.3 & -0.6 \\
\hline 1 - MNCO3-736F-2 & $3.52 \mathrm{Ab}$ & $1.84 \mathrm{Bc}$ & $1.06 \mathrm{Ca}$ & $3.27 \mathrm{Ad}$ & $2.28 \mathrm{Bd}$ & $2.00 \mathrm{Ba}$ \\
\hline 2 - MNCO3-737F-5-11 & $1.95 \mathrm{Ad}$ & $1.70 \mathrm{Ac}$ & $0.72 \mathrm{Bb}$ & $2.03 \mathrm{Ae}$ & $0.97 \mathrm{Be}$ & $0.90 \mathrm{Bb}$ \\
\hline 3 - MNCO3-736F-6 & $3.48 \mathrm{Ab}$ & $1.97 \mathrm{Bc}$ & $1.21 \mathrm{Ca}$ & $4.38 \mathrm{Ac}$ & $2.25 \mathrm{Bd}$ & $1.26 \mathrm{Cb}$ \\
\hline 4 - MNCO2-675F-3 & $3.62 \mathrm{Ab}$ & $1.85 \mathrm{Bc}$ & $0.71 \mathrm{Cb}$ & $6.05 \mathrm{Ab}$ & $2.15 \mathrm{Bd}$ & $1.72 \mathrm{Ba}$ \\
\hline 5 - MNCO3-737F-11 & $3.62 \mathrm{Ab}$ & $1.89 \mathrm{Bc}$ & $1.14 \mathrm{Ca}$ & $4.65 \mathrm{Ac}$ & $2.69 \mathrm{Bc}$ & $2.10 \mathrm{Ba}$ \\
\hline 6 - MNCO2-689F-2-8 & $1.57 \mathrm{Ad}$ & $1.52 \mathrm{Ac}$ & $1.35 \mathrm{Aa}$ & $1.63 \mathrm{Ae}$ & $1.21 \mathrm{ABd}$ & $0.71 \mathrm{Bb}$ \\
\hline 7 - MNCO3-737F-5-1 & $1.97 \mathrm{Ad}$ & $1.19 \mathrm{Bd}$ & $0.88 \mathrm{Bb}$ & $3.51 \mathrm{Ad}$ & $0.97 \mathrm{Be}$ & $1.09 \mathrm{Bb}$ \\
\hline 8 - MNCO3-737F-5-10 & $3.76 \mathrm{Ab}$ & $2.55 \mathrm{Bb}$ & $1.38 \mathrm{Ca}$ & $6.62 \mathrm{Aa}$ & $2.84 \mathrm{Bc}$ & $1.81 \mathrm{Ca}$ \\
\hline 9 - MNCO2-677F-5 & $1.65 \mathrm{Ad}$ & $1.07 \mathrm{Ad}$ & $1.04 \mathrm{Aa}$ & $2.35 \mathrm{Ae}$ & $0.70 \mathrm{Be}$ & $0.57 \mathrm{Bb}$ \\
\hline 10 - MNCO2-675F-4-10 & $4.07 \mathrm{Ab}$ & $1.58 \mathrm{Bc}$ & $1.11 \mathrm{Ba}$ & $6.62 \mathrm{Aa}$ & $3.00 \mathrm{Bc}$ & $2.21 \mathrm{Ba}$ \\
\hline 11 - MNCO2-675F-9-5 & $2.98 \mathrm{Ac}$ & $1.54 \mathrm{Bc}$ & $0.86 \mathrm{Cb}$ & $5.49 \mathrm{Ab}$ & $2.97 \mathrm{Bc}$ & $0.89 \mathrm{Cb}$ \\
\hline 12 - MNCO3-737F-5-9 & $1.91 \mathrm{Ad}$ & $1.69 \mathrm{Ac}$ & $1.39 \mathrm{Aa}$ & 3.08Ad & $1.46 \mathrm{Be}$ & $0.76 \mathrm{Bb}$ \\
\hline 13 - BRS-Tumucumaque & $1.63 \mathrm{Ad}$ & $1.26 \mathrm{~A}$ & $1.15 \mathrm{Aa}$ & $1.71 \mathrm{Ae}$ & $0.94 \mathrm{ABe}$ & $0.80 \mathrm{Bb}$ \\
\hline 14 - MNCO2-675F-9-3 & $1.55 \mathrm{Ad}$ & $1.12 \mathrm{Ad}$ & $0.69 \mathrm{Bb}$ & $1.41 \mathrm{Ae}$ & $0.75 \mathrm{Be}$ & $0.71 \mathrm{Bb}$ \\
\hline 15 - MNCO3-736F-7 & $1.46 \mathrm{Ad}$ & $1.20 \mathrm{Ad}$ & $1.11 \mathrm{Aa}$ & 1.39Ae & $1.40 \mathrm{Ae}$ & $1.08 \mathrm{Bb}$ \\
\hline 16 - MNCO2-677F-2 & $1.78 \mathrm{Ad}$ & $1.64 \mathrm{Ac}$ & $0.95 \mathrm{Bb}$ & 1.69Ae & $2.49 \mathrm{ABd}$ & $0.83 \mathrm{Bb}$ \\
\hline 17 - BR17-Gurgueia & $5.59 \mathrm{Aa}$ & $3.44 \mathrm{Ba}$ & $0.96 \mathrm{Cb}$ & $5.77 \mathrm{Ab}$ & $3.28 \mathrm{Bb}$ & $1.46 \mathrm{Cb}$ \\
\hline 18 - BRS-Pajeú & $1.80 \mathrm{Ad}$ & $1.75 \mathrm{Ac}$ & $1.42 \mathrm{Aa}$ & $3.02 \mathrm{ABd}$ & $4.25 \mathrm{Aa}$ & $2.41 \mathrm{Ba}$ \\
\hline 19 - Paulistinha & $1.98 \mathrm{Ad}$ & $1.57 \mathrm{Ac}$ & $0.52 \mathrm{Bb}$ & $1.69 \mathrm{ABe}$ & $2.18 \mathrm{Ad}$ & $0.85 \mathrm{Bb}$ \\
\hline $\mathrm{CV}(\%)$ & & 11.83 & & & 13.91 & \\
\hline
\end{tabular}

Equal lowercase letters in the column do not differ from the Scott and Knott test $(\mathrm{p}<0.05)$, and the same upper case letters in the row do not differ from the Tukey test $(\mathrm{p}<0.05)$.

The shoot dry matter accumulation of the genotypes 2 - MNCO3-737F-5-11, 6 - MNCO2689F-2-8, 7 - MNCO3-737F-5-1, 12 - MNCO3737F-5-9 and 19 - Paulistinha decreased significantly $(p<0.05)$ with the reduction in the osmotic potential of the substrate from 0.0 MPa to $0.6 \mathrm{MPa}$ (Table 3). However, the genotypes 11 MNCO2-675F-9-5, 15 - MNCO3-736F-7 and 17 BR17-Gurgueia increased the accumulation of shoot dry matter due to the reduction in the osmotic potential of the substrate from $0.0 \mathrm{MPa}$ to $-0.6 \mathrm{MPa}$, which is related to the small growth and, consequently, the non-consumption of seed reserves, corroborating the low dry matter accumulation in the radicle. Thus, the higher accumulation of dry matter is related to the seed and not to the plantlet (Tables 2 and 3). However, the reduction in seed vigor caused by the salt stress, retards the establishment of the plants at field and is due to the decrease in the mobilization of reserves and induction of disorders in the cell membranes, caused by the increase in the osmotic pressure of the soil solution, reducing the availability of water to the seeds (BARRETO et al., 2010; ALMEIDA et al., 2012; COELHO et al., 2014). 
Table 3. Dry shoot mass (DSM) and radicle (DRM) of cowpea genotypes under saline stress.

\begin{tabular}{|c|c|c|c|c|c|c|}
\hline \multirow{3}{*}{ Genótipos } & \multicolumn{3}{|c|}{$\operatorname{DSM}(\mathrm{g})$} & \multicolumn{3}{|c|}{$\mathrm{DRM}(\mathrm{g})$} \\
\hline & \multicolumn{6}{|c|}{ Osmotic potential (MPa) } \\
\hline & 0.0 & -0.3 & -0.6 & 0.0 & -0.3 & -0.6 \\
\hline 1 - MNCO3-736F-2 & $0.591 \mathrm{Ac}$ & $0.462 \mathrm{Ad}$ & $0.615 \mathrm{Ab}$ & $0.011 \mathrm{Ad}$ & $0.012 \mathrm{Ac}$ & $0.009 \mathrm{Ab}$ \\
\hline 2 - MNCO3-737F-5-11 & $0.793 \mathrm{Ab}$ & $0.615 \mathrm{Bc}$ & $0.545 \mathrm{Cc}$ & $0.018 \mathrm{Ac}$ & $0.004 \mathrm{Bd}$ & $0.006 \mathrm{Bb}$ \\
\hline 3 - MNCO3-736F-6 & $0.637 \mathrm{Ac}$ & $0.615 \mathrm{Ac}$ & $0.718 \mathrm{Aa}$ & $0.013 \mathrm{ABd}$ & $0.018 \mathrm{Ac}$ & $0.009 \mathrm{Bb}$ \\
\hline 4 - MNCO2-675F-3 & $0.545 \mathrm{Ac}$ & $0.547 \mathrm{Ac}$ & $0.647 \mathrm{Ab}$ & $0.032 \mathrm{Ab}$ & $0.021 \mathrm{ABb}$ & $0.016 \mathrm{Ba}$ \\
\hline 5 - MNCO3-737F-11 & $0.640 \mathrm{Ac}$ & $0.635 \mathrm{Ac}$ & $0.673 \mathrm{Aa}$ & $0.022 \mathrm{Ac}$ & $0.016 \mathrm{ABc}$ & $0.013 \mathrm{Bb}$ \\
\hline 6 - MNCO2-689F-2-8 & $0.999 \mathrm{Aa}$ & $0.719 \mathrm{Bb}$ & $0.768 \mathrm{Ba}$ & $0.018 \mathrm{Ac}$ & $0.009 \mathrm{AB}$ & $0.006 \mathrm{Bb}$ \\
\hline 7 - MNCO3-737F-5-1 & $0.727 \mathrm{Ab}$ & $0.600 \mathrm{ABc}$ & $0.538 \mathrm{Bc}$ & $0.022 \mathrm{Ac}$ & $0.003 \mathrm{Bd}$ & $0.004 \mathrm{Bb}$ \\
\hline 8 - MNCO3-737F-5-10 & $0.564 \mathrm{Bc}$ & $0.550 \mathrm{Bc}$ & $0.710 \mathrm{Aa}$ & $0.034 \mathrm{Ab}$ & $0.010 \mathrm{Bd}$ & $0.014 \mathrm{Ba}$ \\
\hline 9 - MNCO2-677F-5 & $0.641 \mathrm{Ac}$ & $0.739 \mathrm{Ab}$ & $0.765 \mathrm{Aa}$ & $0.020 \mathrm{Ac}$ & $0.010 \mathrm{Bd}$ & $0.012 \mathrm{Bb}$ \\
\hline 10 - MNCO2-675F-4-10 & $0.631 \mathrm{Bc}$ & $0.716 \mathrm{ABb}$ & $0.858 \mathrm{Aa}$ & $0.050 \mathrm{Aa}$ & $0.021 \mathrm{Bb}$ & $0.025 \mathrm{Ba}$ \\
\hline 11 - MNCO2-675F-9-5 & $0.565 \mathrm{Bc}$ & $0.706 \mathrm{ABb}$ & 0.749Aa & $0.035 \mathrm{Ab}$ & $0.013 \mathrm{Bc}$ & $0.008 \mathrm{Bb}$ \\
\hline 12 - MNCO3-737F-5-9 & $0.830 \mathrm{Aa}$ & $0.594 \mathrm{Bc}$ & $0.542 \mathrm{Bc}$ & $0.030 \mathrm{Ab}$ & $0.007 \mathrm{Bd}$ & $0.003 \mathrm{Bb}$ \\
\hline 13 - BRS-Tumucumaque & $0.722 \mathrm{Ab}$ & $0.736 \mathrm{Ab}$ & $0.786 \mathrm{Aa}$ & 0.006Ad & 0.010Ad & $0.007 \mathrm{Ab}$ \\
\hline 14 - MNCO2-675F-9-3 & $0.901 \mathrm{Aa}$ & $0.814 \mathrm{Aab}$ & $0.826 \mathrm{Aa}$ & $0.030 \mathrm{Ab}$ & $0.014 \mathrm{Bc}$ & $0.007 \mathrm{Bb}$ \\
\hline 15 - MNCO3-736F-7 & $0.685 \mathrm{Bc}$ & $0.696 \mathrm{Bb}$ & $0.832 \mathrm{Aa}$ & $0.005 \mathrm{Ad}$ & $0.007 \mathrm{Ad}$ & $0.004 \mathrm{Ab}$ \\
\hline 16 - MNCO2-677F-2 & $0.767 \mathrm{Ab}$ & $0.880 \mathrm{Aa}$ & $0.737 \mathrm{Aa}$ & $0.013 \mathrm{AB}$ & $0.020 \mathrm{Ab}$ & $0.006 \mathrm{Bb}$ \\
\hline 17 - BR17-Gurgueia & $0.304 \mathrm{Bd}$ & $0.322 \mathrm{ABe}$ & $0.473 \mathrm{Ac}$ & $0.017 \mathrm{Ac}$ & $0.026 \mathrm{Ab}$ & $0.018 \mathrm{Aa}$ \\
\hline 18 - BRS-Pajeú & $0.730 \mathrm{Ab}$ & $0.775 \mathrm{Ab}$ & $0.641 \mathrm{Ab}$ & $0.018 \mathrm{ABc}$ & $0.030 \mathrm{Aa}$ & $0.012 \mathrm{Bb}$ \\
\hline 19 - Paulistinha & $0.865 \mathrm{ABa}$ & $0.953 \mathrm{Aa}$ & $0.731 \mathrm{Ba}$ & $0.017 \mathrm{Ac}$ & $0.019 \mathrm{Ac}$ & $0.007 \mathrm{Bb}$ \\
\hline
\end{tabular}

$\mathrm{CV}(\%)$

13.38

12.38

Equal lowercase letters in the column do not differ from the Scott and Knott test $(\mathrm{p}<0.05)$, and the same upper case letters in the row do not differ from the Tukey test $(\mathrm{p}<0.05)$.

Regarding the plantlets subjected to salt stress, vigor is more affected than germination, causing greater reduction of biomass, which can be attributed to the decrease in cell division and expansion, leading to a loss of yield by the plant (SANTOS et al. 2009; ALMEIDA et al., 2012; LOPES et al., 2014; BERNARDES et al., 2015). However, some materials exhibit better performance under salt stress conditions, as observed in the genotypes 4 - MNCO2-675F-3, 8 - MNCO3-737F5-10, 10 - MNCO2-675F-4-10 and 17 - BR17Gurgueia, which showed the highest accumulation of radicle dry matter at the osmotic potential of -0.6 $\mathrm{MPa}$, in relation to the other studied genotypes (Table 3).

The genotypes 1 - MNCO3-736F-2, 13 BRS-Tumucumaque, 15 - MNCO3-736F-7 and 17 BR17-Gurgueia were not influenced by the increase in salinity, but they showed the lowest accumulations of dry matter, even in the control treatment $(0.0 \mathrm{MPa})$. This indicated lower development and probably consumption of seed reserves for plantlet growth, which is consistent with the results for shoot dry matter (Table 3 ).

\section{CONCLUSIONS}

The increase in salinity affects germination and initial growth of the cowpea genotypes.

The genotypes 6 - MNCO2-689F-2-8, 10 MNCO2-675F-4-10, 12 - MNCO3-737F-5-9, 16 MNCO2-677F-2, 18 - BRS-Pajeú and 19 Paulistinha are the most tolerant to the salt stress in the stage of germination and initial growth.

The genotypes 11 - MNCO2-675F-9-5, 13 BRS-Tumucumaque, 15 - MNCO3-736F-7 and 17 BR17-Gurgueia are the most sensitive to salt stress in the stage of germination and initial growth. 
RESUMO: O estresse salino é um fenômeno frequente em regiões áridas e semiáridas do globo, afetando a produção agrícola dessas regiões, sendo necessário lançar mão de estratégias que minimizem os impactos do estresse salino sob agricultura, para isso é necessário a incorporação de espécies, variedade e genótipos tolerantes para aumentar a produção nessas regiões. Assim, objetivou-se com esse trabalho avaliar a germinação e o crescimento inicial de genótipos de feijão-caupi sob estresse salino. Utilizou-se de um delineamento experimental inteiramente casualizado em esquema fatorial $19 \times 3$, constituído de dezenove cultivares de feijão-caupi e três potenciais osmóticos, com quatro repetições de 50 sementes cada. O teste de germinação teve duração de oito dias, quando as sementes foram avaliadas a quanto à percentagem de germinação, índice de velocidade de germinação, comprimento da parte aérea e da raiz, acúmulo de massa seca da parte aérea e da raiz. O aumento da salinidade afetou a germinação e o crescimento inicial dos genótipos de feijãocaupi. Os genótipos 6 - MNCO2-689F-2-8, 10 - MNCO2-675F-4-10, 12 - MNCO3-737F-5-9; 16 - MNCO2-677F-2; 18 BRS-Pajeú e 19 - Paulistinha apresentaram maior tolerância ao estresse salino na fase de germinação e crescimento inicial. Os genótipos 11 - MNCO2-675F-9-5, 13 - BRS-Tumucumaque; 15 - MNCO3-736F-7 e 17 - BR17-Gurgueia foram mais suscetíveis aos efeitos do estresse salino na fase de germinação e crescimento inicial.

PALAVRAS-CHAVE: Fisiologia de Sementes. Germinação. Salinidade da água.

\section{REFERENCES}

ALMEIDA, W. S.; FERNANDES, F. R. B.; BERTINI, C. H. C. M.; PINHEIRO, M. S.; TEÓFILO, E. M. Emergência e vigor de plântulas de genótipos de feijão-caupi sob estresse salino. Revista Brasileira de Engenharia Agrícola e Ambiental, Campina Grande, v. 16, n. 10, p. 1047-1054, out. 2012. https://doi.org/10.1590/S1415-43662012001000003

AYERS, R. S.; WESTCOT, D. W. A qualidade de água na agricultura. 2.ed. Campina Grande: UFPB, 1999. 153p. FAO. Irrigação e Drenagem.

BARRETO, H. B. F.; FREITAS, R. M. O.; OLIVEIRA, L. A. A.; ARAUJO, J. A. M.; COSTA, E. M. Efeito da irrigação com água salina na germinação de sementes de sabiá (Mimosa caesalpiniifolia Benth). Revista Verde de Agroecologia e Desenvolvimento Sustentável, Mossoró, v. 5, n. 3, p. 125-130, jul./set. 2010.

BERNARDES, P. M.; MENGARDA, L. H. G.; LOPES, J. C.; NOGUEIRA, M. U.; RODRIGUES, L. L. Qualidade fisiológica de sementes de repolho de alta e baixa viabilidade sob estresse salino. Revista Nucleus, Ituverava, v. 12, n. 1, p. 77-86, abr. 2015.

COELHO, J. B. M.; BARROS, M. F. C.; BEZERRA NETO, E.; SOUZA, E. R. Ponto de murcha permanente fisiológico e potencial osmótico de feijão-caupi cultivado em solos salinizados. Revista Brasileira de Engenharia Agrícola e Ambiental, Campina grande, v. 18, n. 7, p. 708-713, jul. 2014. http://dx.doi.org/10.1590/S1415-43662014000700006.

FERREIRA, D. F. Sisvar: a computer statistical analysis system. Ciência e Agrotecnologia, Lavras, v. 35, n. 6, p. 1039-1042, jun. 2011. http://dx.doi.org/10.1590/S1413-70542011000600001.

LIMA, J. R. S.; ANTONINO, A. C. D.; LIRA, C. A. B. O.; SOUZA, E. S.; SILVA, I. F. Balanço de energia e evapotranspiração de feijão caupi sob condições de sequeiro. Revista Ciência Agronômica, Fortaleza, v. 42, n. 1, p. 65-74, jan./mar. 2011. https://doi.org/10.1590/S1806-66902011000100009

LOPES, K. P.; NASCIMENTO, M. G. R.; BARBOSA, R. C. A.; COSTA, C. C. Salinidade na qualidade fisiológica em sementes de Brassicas oleracea L. Var. Itálica. Semina: Ciências Agrárias, Londrina, v. 35, n. 5, p. 2251-2260, set./out. 2014. https://doi.org/10.5433/1679-0359.2014v35n5p2251

MAGUIRE, J. D. Speed of germination-aid in selection and evaluation for seedling emergence and vigor. Crop Science, Madson, v. 2, n. 1, p. 176-177, mar. 1962.

MUNNS, R.; TESTER, M. Mechanism of salinity tolerance. Annual Review of Plant Biology, Palo Alto, v. 59, n. 6, p. 651-681, jun. 2008. https://doi.org/10.1146/annurev.arplant.59.032607.092911 
MURTAZA, G.; GHAFOOR. A.; QADIR, M. Irrigation and soil management strategies for using saline-sodic water in a cotton-wheat rotation. Agricultural Water Management, Amsterdam, v. 81, n. 1-2, p. 98-114, fev. 2006. https://doi.org/10.1016/j.agwat.2005.03.003

NAKAGAWA, J. Testes de vigor baseados no desempenho das plântulas. In: KRZYZANOSKI, F. C. et al. (Ed.). Vigor de sementes: conceitos e testes. Londrina: ABRATES, 1999. p . 2.1-2.24.

OLIVEIRA, F. S.; SÁ, F. V. S.; SOUTO, L. S.; PAIVA, E. P.; OLIVEIRA, F. A.; ARAÚJO, E. B. G.; OLIVEIRA NETO, H. T.; MESQUITA, E. F. Seedling of development and tolerance of eggplant cultivars under saline stress. African Journal of Agricultural Research, Nairobi, v. 11, n. 26, p. 2310-2315, jun. 2016. https://doi.org/10.5897/AJAR2016.11245

SÁ, F. V. S.; SOUTO, L. S.; PAIVA, E. P.; FERREIRA NETO, M.; SILVA, R. A.; SILVA, M. K. N.; MESQUITA, E. F.; ALMEIDA, F. A.; ALVES NETO, A. Tolerance of coriander cultivars under saline stress. African Journal of Agricultural Research, Nairobi, v. 11, n. 39, p. 3728-3732, set. 2016. https://doi.org/10.5897/AJAR2016.11390

SANTOS, P. R.; RUIZ, H. A.; NEVES, J. C. L.; ALMEIDA, E. F.; FREIRE, M. B. G. S.; FREIRE, F. J. Germinação, vigor e crescimento de cultivares de feijoeiro em soluções salinas. Revista Brasileira de Engenharia Agrícola e Ambiental, Campina Grande, v. 13, p. 882-889, dez. 2009. https://doi.org/10.1590/S1415-43662009000700010

SCHEEREN, B. R.; PESKE, S. T.; SCHUCH, L. O. B.; BARROS, A. C. A. Qualidade fisiológica e produtividade de sementes de soja. Revista Brasileira de Sementes, Londrina, v. 32, n.3, p. 35-41, set. 2010. https://doi.org/10.1590/S0101-31222010000300004

TAIZ, L.; ZEIGER, E. Fisiologia vegetal. 6. ed. Porto Alegre: ARTMED. 2013. 719 p. 